\title{
Identifying the Potential of Health Tourism in Pasargadae Region, Iran
}

\author{
By Farzaneh Gerami ${ }^{*}$, Seyedh Zohreh Hosseini", \\ Masoud Nakhaei Ashtari ${ }^{\mp}$ \& Hamid Fadaei ${ }^{\S}$
}

\begin{abstract}
Health tourism is one of the most influential parameters that can play a significant role in the tourism development of the country. Although this concept has been given special attention in the developed countries, developing countries such as Iran, in spite of the richness of capabilities and potentials, have not made a worthwhile investment in this field. Despite the fact that health tourism in Iran is in its infancy, it can strengthen its foundations in Iran by creating new opportunities and competitiveness of the tourism industry. This paper seeks to provide a first assessment of this emerging phenomenon in the area, which aims at introducing and designing a health tourism centre or health village in the Pasargadae region of Fars province, due to the high potential of this region to attract tourists and excellent positions to construct health village. For this purpose, by identifying strengths and opportunities for sustainable health tourism development, as well as by examining challenging issues and threats, guidelines for converting the weaknesses into opportunities, and effectual usage of strengths and positive points with the applicable approach are presented.
\end{abstract}

Keywords: Pasargadae, Traditional Medicine, Medical Herb, Tourism Development, Health Tourism.

\section{Introduction}

Nowadays, due to environmental pollution in the crowded city, and the aging of the population and long time working, constructing a place for personal and social health seems essential. Health tourism is an alternative for people who care more about their health and welfare and are longing to flee from their daily stressful life (Vajirakachorn 2004). This type of tourism can be seen in all ages, but on average, 45-year-old women have shown the highest tendency for wellbeing tourism. Generally, The customers who are eager for this type of tourism, have high levels of income and education (Smith 2010). Health tourism comprises three separate categories including Medical Tourism, Curative Tourism, and Wellness Tourism.

Fars province is one of the most popular destinations in Iran and is known as a medical pole in the south of Iran that has achieved a noticeable reputation in transplant surgeries (especially kidney, liver and corneal), infertility treatment,

\footnotetext{
*Head of Tourism Department, Pasargadae World Heritage Site, Iran.

${ }^{\dagger}$ Vice President for Research, Pasargadae World Heritage Site, Iran.

*Conservation and Restoration Expert, Pasargadae World Heritage Site, Iran.

${ }^{\S}$ Site Manager, Pasargadae World Heritage Site, Iran.
} 
cosmetic and vital surgeries that lead to being one of the main purposes for medical tourism. Annually numerous patients from adjacent countries arrive in Shiraz (Capital of Fars) in hopes of seeking health and visiting attractive places. Though Fars has considered itself as a high-rank place to have the most attractive monuments and sightseeing, unfortunately, it has not been through a deep survey in terms of absorbing patients (Rokni et al. 2013). The existence of a health village far from urban congestion and pollution can improve this industry in this province as a consequence of encouraging patients to travel and using health services. One of the best advantages of a health village is reducing the course of treatment to recover the patients who survived the serious disease. Another one is preventing and controlling mental diseases and hurry sicknesses such as anxiety, stress or depression that roots from crowd and pollution in the megacity by nature health treatment or wellbeing courses in the health village. This study is aimed to introduce one of the best occasions for creating a health village in Fars and clarifying all aspects of health tourism in this region due to the potential opportunities and challenges.

\section{Literature Review}

Health tourism programs in Iran were first launched in 2002 by the ministry of health, treatment and medical education (initiation of the 4th development), and some facilities and ads are allocated for developing this industry in the middle east state, that was welcomed by numerous visitors from Islamic countries or the Persian Gulf state (Izadi et al. 2013). Iran is intended for entering into this industry with the advantages of health tourism including low-cost services with high quality, skilled doctors, and numerous natural attractions (Shalbafian 2006). However, due to political tensions, the uncertainty of the promise to accept western tourists remains to be seen. Previous studies in Iran demonstrate that this country embraces the high potential to attract tourists seeking treatment and enjoying sightseeing at the same time (Kazemi 2007, Jabbari 2009). The lack of comprehensive planning systems for health tourism has led to focus on understanding the various aspect of this process in the relevant studies, moreover providing practical solutions and suggestions in terms of planning and strategies for medical and health tourism (Shalbafian 2006, Bakhtiari 2005). Identifying potentials, challenges and obstacles for the development of this industry in Iran are argued in various research and considers a methodology for analyzing Iran's health tourism resources, which has led to the introduction of various cities for constructing a site, known as wellness tourism center such as Shiraz in Fars province, Isfahan in Isfahan province and Sareyn in Ardabil province (Nadim and Gandomkar 2016, Rokni et al. 2013, Tourani et al. 2010). Determining the executable and effective parameters for appealing medical tourism have illustrated the massive potential of health tourism in Iran in the region to become a pole in the future. However, accelerating the visa process for patients and their relatives, presenting accommodation and leisure facilities for relatives of patients, strengthening 
collaboration between tourism organizations, diversification of medical tourism services, increasing the quality and reducing the expenses can facilitate the progression of medical tourism (Kazemi 2007).

\section{Methodology}

In order to achieve research issues, a descriptive and analytical method was used. This descriptive review article was done in two stages. First, the research data was extracted from the literature review, library study and field survey. The method of approach for the analyzing data conducted by means of the strategy model of SWOT for clarifying all aspects of health tourism in this region. SWOT analysis has been used to identify the main internal and external factors to achieve the goal. For this, internal (strengths and weaknesses) and external (threats and opportunities) environments were studied and a list of strengths, weaknesses, opportunities, and threats has been provided.

\section{The Geographic Condition of Pasargadae Region}

Pasargadae region is located in north-east of Fars province and has a remarkable potential for creating a health village with temperate weather (see Figure 1). This region consists of 5 rural areas and 6,532 inhabitants (permanent residents and nomads). The region includes Kord-shoul village with 850 inhabitants, Madar-Soleyman with 1605 inhabitants, Mobarak-Abad with 1288 inhabitants, Abolvardi with 2641 inhabitants and Dehno with 148 inhabitants (see Figure 2). This region is well-known by Pasargadae world heritage site, the first dynastic capital of the Achaemenid Empire, founded by Cyrus the Great, in Pars, the land of the Persians in the 6th century BC. High Zagros mountain and Morghab plain have created fabulous multiple valleys in this area with a rich ecosystem that attracts numerous tourists and adventurers each year. This capability is known as one of the strong positive points in creating a health village due to precious history, pleasant weather, the unique nature, and particular lifestyle (Gholipour 2005).

Figure 1 illustrates the situation of Pasargadae in Iran and other neighboring countries which are willing to travel for health reasons to Shiraz. Pasargadae region can absorb these visitors due to noticeable natural and historical resources. The number of annual visits to Pasargadae world heritage site by Iranian and overseas residents is presented in Graph 1. In 2017, more than 50,000 foreign tourists visited Pasargadae world heritage site that reaches a peak from 1997 and can be known as a consequence of the political position of Iran in the middle east and the world. This data shows the high potential of this region to increase the number of tourists by introducing other attractions such as health opportunities. 
Figure 1. A Sketch Map of the Location of Shiraz and Pasargadae in Fars Province

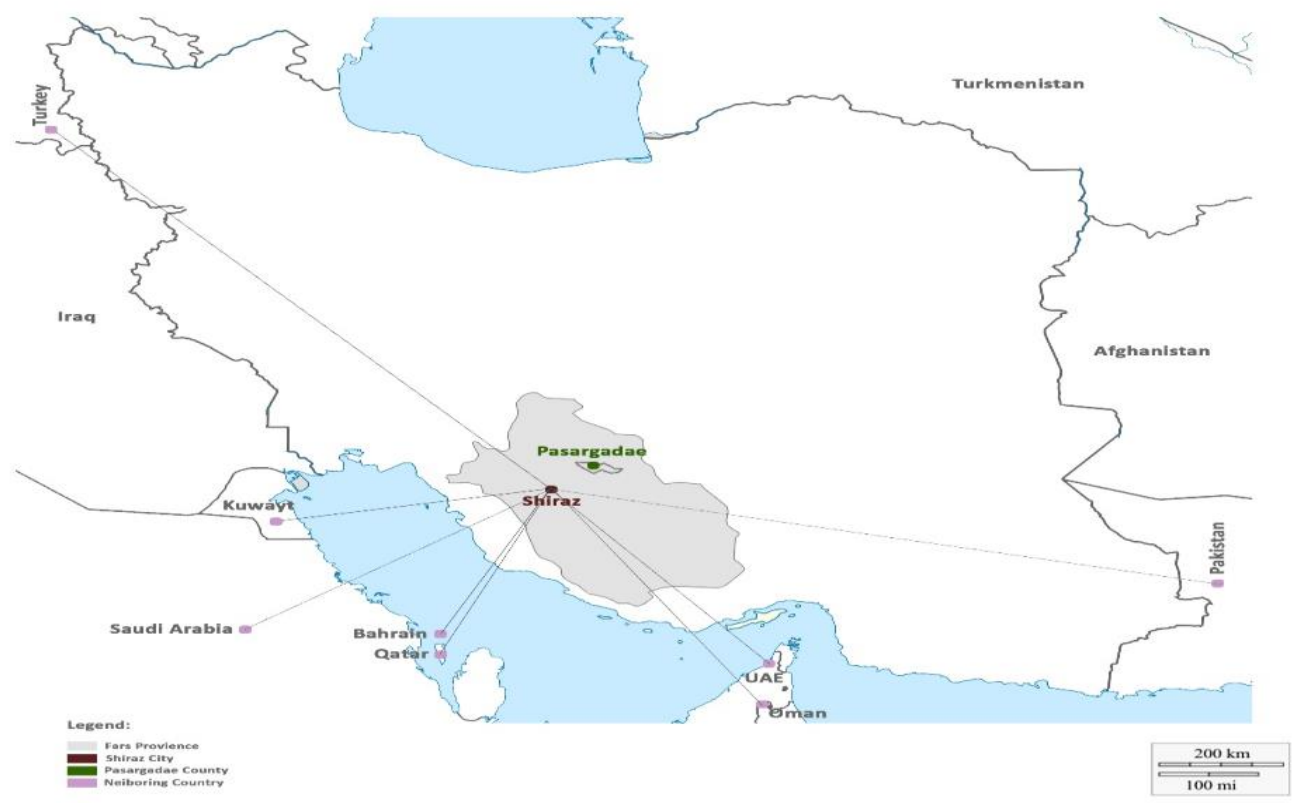

Source: Authors (2019).

Figure 2. An Aerial Photo of Pasargadae Region

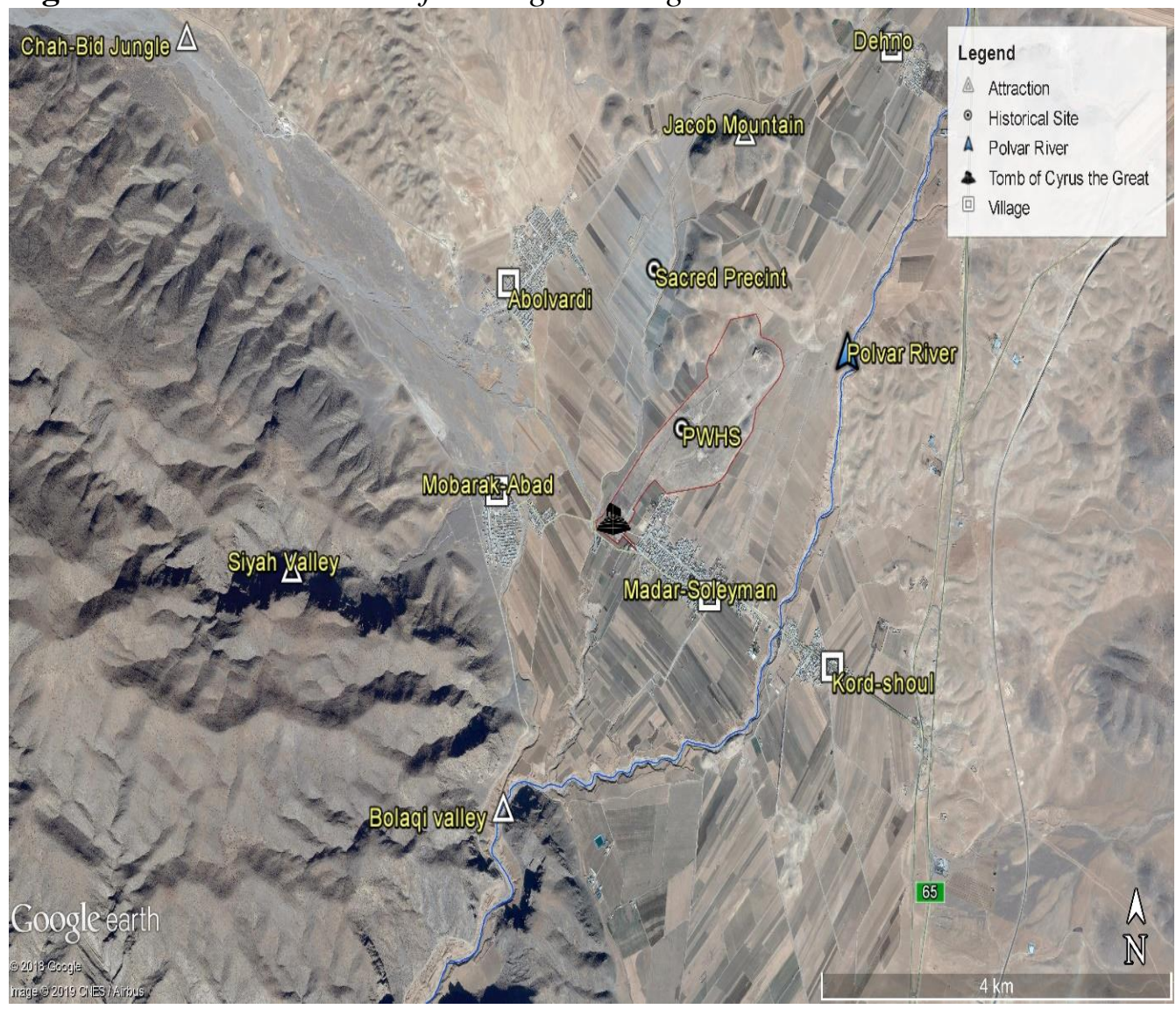

Source: Authors (2019). 
Graph 1. The Line Chart of Iranian and Foreign Visitors that Inter to Pasargadae Region from 1997 to 2017

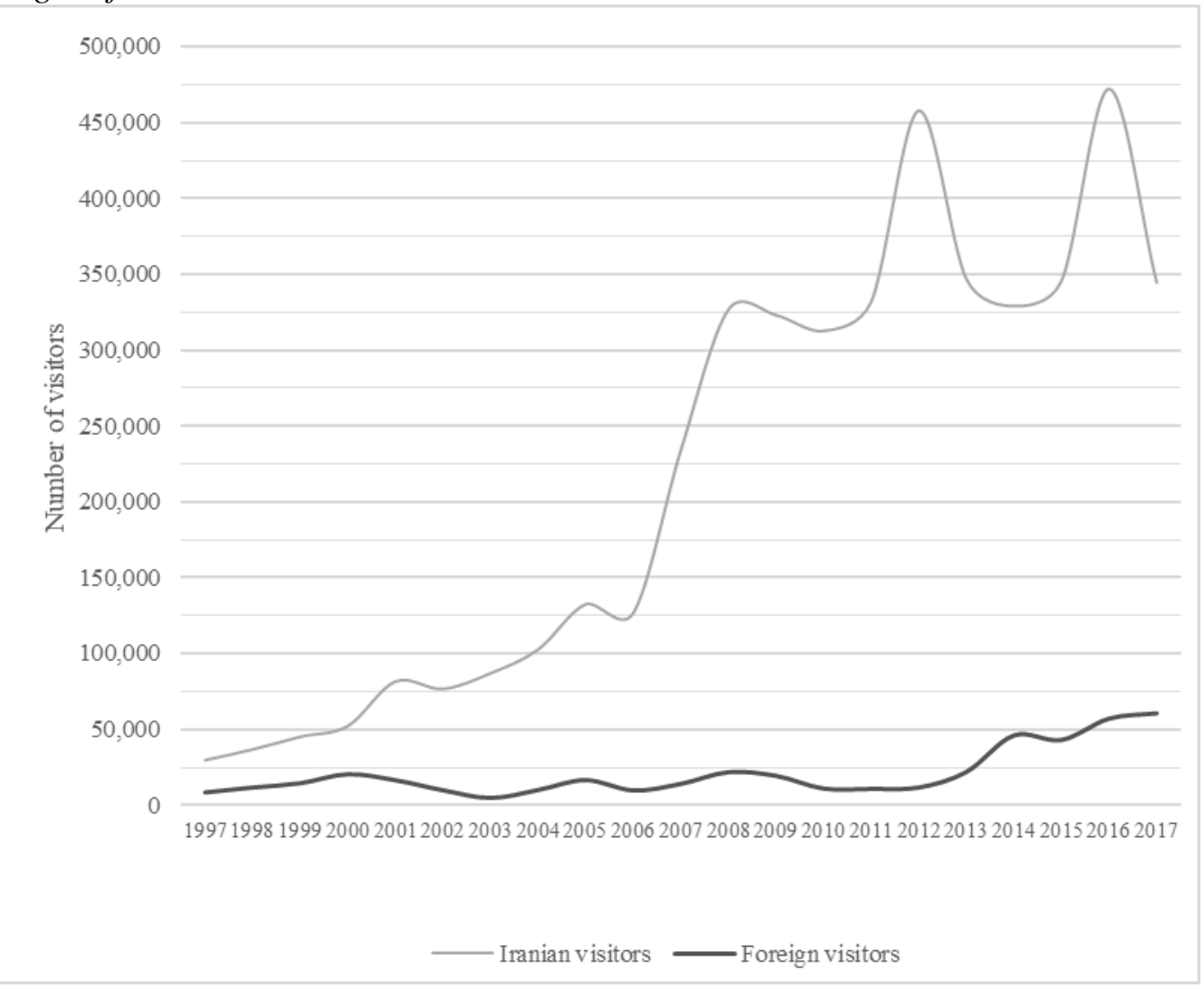

Source: Archive of Pasargadae Research Centre, 2018.

\section{Potential of Health Tourism in Pasargadae Region}

Consistent travel for health and medical reasons in this region is nothing new and Cyrus II the Great mausoleum had long been recognized as a healer for visitors and locals. In the past, herders had blessed their animals around the tomb to protect against rabies or wild animals' attack or washing their body or animals in the Polvar river for healing reasons. Another example is a Hazrat-e Yaqub (Jacob holiness) mountain which has special respect between locals. In specific ceremonies, locals climb this mountain with the hope to cure their diseases by numerous energy of Jacob holiness. In addition to the local beliefs, this region is perfectly coinciding with healthiness tourism centre or health village due to remarkable potentials such as natural facilities without demanding chemical medicines, operations for healthy people in all age categories, traditional medicine, and diversity of medical herbs. Natural facilities include fresh air, various medical herb, clean water, safe environment, and a beautiful landscape with mountain and plain (Sedaghat Kish 2000). 


\section{The Pure Nature}

In Iranian culture, a mountain is considered sacred. It is fertile and provides water and pasture for the herd. In ancient Iranian beliefs, mountains were considered as the place of descent of prophets, the location for light and water and shelter for most freedom lovers. The tough conditions and seclusion nature of mountains, have converted them to original incomparable birthplaces of ancient cultures in which profound interwoven ties between humans and nature are clearly observable (Irani Behbahani et al. 2010). Pasargadae region as the best example of this case is located in Morghab plain which belongs to the "High Zagros" zone and its long-lasting civilization date back to 3000 BC (Samani 2002). Having various lifestyles and several ecosystems in this region on one hand and the shape of mountain folds surrounding it, on the other hand, have provided a proper natural, geographical and strategic basis to establish the civilization from ancient time to now (Irani Behbahani et al. 2010). Mountain-plain region contains permanentseasonal flows of Polvar-Sivand River and its several branches have provided proper natural conditions for different types of native plants and wild animals (Bahrami et al. 2007). Clean environment and fresh air contribute to distance of city pollution and crowded, soothing sunlight, wonderful skyline and virgin nature such as Bolaqi valley or Chah-Bid jungle, create a suitable place for nature therapy and raise of healing power that are within each person. In the Pasargadae region, the existence of a swamp in the Bolaqi valley will be provided with the possibility of using therapeutic natural mud. Hearing the music of nature due to the far distance of city centres, provide the incredible opportunity to meditate. Meditation as a therapeutic method causes physiological changes by regulating concentration on chosen subjects (audio and the image) in the specified time period (Ghafari et al. 2008). Yoga means the union of body, mind, and spirit, uses the natural energy as another kind of therapy, and work on the mental and physical health in the same time to reduce stress, improves breathing, making the powerful and flexible body (Hosseini et al. 2008) and (Gabor and Oltean 2019).

\section{The Particular Lifestyle}

Iranian shepherds and farmers have always adapted themselves to nature since ancient times. Some of them have chosen the nomadic system and proper seasonal migrations as their lifestyle due to severe climatic changes and differences in topographic elevations. Such a nomadic group, the Qashqa'i, Baseri, Khamseh, and Arab Sheibani pastoralists (Saeedi 2005) have chosen the seasonal migration in harmony with nature's variations and during different seasons of the year as a way to achieve a cheap resource of provender and frequent pastures throughout the year and also to avoid drought and frost (Beck 1998). Tang-e Khersi (Beer valley), Tang-e Bolaqi (Bolaqi valley), Tang-e Khoshk (Dry valley), and Tang-e Siyah (Black valley) in the Pasargadae region, are the major routes of the nomads (Qashqa'i, Baseri, Khamseh, and Arab Sheibani pastoralists) that coincident with ancient rout lies of Achaemenian. In this region, the layers of life in terms of 
nature and history are so interwoven that the signs and symbols of culture, from ancient ages up to now, can be traced and comprehended despite the passage of the time and the overlapping of consistent trends of life in the form of novel structures and natural changes.

This particular lifestyle can improve people's physical health by eating fresh and organic food, healthy and light diet, heavy daily exercises and breathing fresh air. On the other hand, living in nature with animals, feeling a relationship with family and being far from the virtual world can treat mental diseases. It would decrease loneliness, sense of isolation and depression, anxiety and arousal sympathetic nervous system and provide motivation for a healthy lifestyle (Sabzalian 2004).

\section{Traditional Medicines}

Using traditional medicine and medicinal herbs in Iran dates back to the time of Babylonian-Assyrian Civilization (Naghibi et al. 2005). Traditional medicine in Iran incorporates a wide range of knowledge on medicines, remedies, maintaining and promotion of health, which focused on the six main factors of climate, food and drink, sleep cycle, movement, and resting discomfort and its relief, and psychological state. This tradition has evolved over the years with the transfer of experiences from generation to generation that contains orally transmitted knowledge and practices or thousands of valuable manuscripts. This philosophy of traditional knowledge as an important part of the communal identity of Iranian is highly respected. In the Pasargadae region, traditional medicine is still alive between locals and nomads. Mostly the old women in the tribe, cure the patients with medical herbs which are prepared by themselves and acquired from other experienced persons, often close family members. To exemplify, locals strongly believe in bonesetters as a traditional orthopedist who has not undergone formal institutional training. They usually have a considerable reputation among locals by using herbal or animal materials for management of sprains and broken bones. They cover the damaged bones or muscles with turmeric, flour and animal oil. Moreover, a number of babies in rural areas are still delivered by local midwives or birth attendants who are not trained in official conventional medicine. These traditional birth attendants also use herbal preparations before or after delivery. In traditional medicine of Pasargadae, one kind of message is implied in the local bath by a traditional masseur that is called "Dalaak". Massages facilitate blood flow and affect subcutaneous cells and muscles, by physical movement on the outer surface of the body. (Hashemian 2004). In the local bath, "Kiseh" and "Sefidab" are an essential part of the bath time routine. Sefidab is a whitecolored substance made of animal fat and naturally occurring minerals. Paired with a Kiseh, scrubbing glove or mitt, Sefidab is an excellent exfoliator and peel for the entire body Furthermore, women applied some herbal powder as a hair care or hair colorings like walnut leaves with Hana and Spand for black color, Chamomile, and Hana for Brown color, Pomegranate hull and Hana for red color. Another kind of therapy is Aromatherapy that due to various herbal 
plants in this region can be applied. Moreover, locals cure Corn disease by turpentine with animal oil or almond resin or use the fruit extract of Ficus carica sylvestris as a verruca remedy.

\section{Medical Herbs}

Pasargadae's specific geographical position and compatible climate make it wonderful grow-land for numerous, delicate, vast and varied medical herbs that attracted local's attention from ancient times. Medical therapy art is a section of Avesta, which as reported by the book, Serita (or Thrita) the first mythical physician, has given thousands of healing plants to Ahora Mazda (The God of Light in the dualistic theology of Zoroastrianism) (Hamedi et al. 2013, Adhami, et al. 2007). A relief in Persepolis (the Achaemenes capital, 500 BC) represents the cosmetic application of oils or herbs extracts which was extensively applied in the ancient civilization of Iran especially as sedative agents used after bathing (Moghadamzadeh et al. 2011).

Extraction of oil-soluble components of medicinal plants was reported in ancient documents and manuscripts, such as lily oil extracts used as topical analgesics (Adhami et al. 2007) or Saffron (Crocus sativus L.) and labdanum oil (Cistus ladanifer L.) as healing products for hand and face skin in as early as 330 BC. (Gershevich 2006). Islam appearance by introducing Iranian scientist in pharmacology and pharmacy, such as Rhazes (850-932) and Avicenna (9801037), played a significant role in the evolution of traditional medical science. Such that during this period, using forty different pharmaceutical dosage forms and developing different kinds of extraction and preparing herbal medicines was considered in the treatment of certain disease such as cancer (Hamedi et al. 2013). According to the Great Iranian physician's beliefs, "there is no pain without a herbal therapy" that is survived in traditional medicine. In the Pasargadae region, most of the residents are the nomad that live in nature by seasonal migration. This person due to the deep relation with nature had a strong knowledge in workability of herbs in their healthy life. More than 275 species are used in the traditional medicine of Qashqa'i pastoralists that shows the rich knowledge of medical herb between them. They believe medical herb is more effective, cheaper and have a less side effect than chemical medicine. The common medical herb is Thymus spp., Anthemis persica, Achillea wilhelmsii, Artemisia persica, Teucrium polium, Anchusa italic, Berberis integrrima, Nigella satvia, Glycyrrhiza glabra, Foeniculum vulgare, Ferula assa-foetida and so forth. Furthermore, They Pastoralists implied medical herbs for curing some disease such as cold, diarrhea, myalgia, embolism, headache, kidney stone, urethra infection, flatulence, stomach ache and so on. Some plants like Crocus satvia, Anthemis persica, Ferulago angulata, Anethum graveolens, Allium sativa, Mentha longifolia used as a spice, Salix excels, Pistacia atlantica, Ziziphus spinachirsti and Berberis integrrima as a chromogen plants, a leaf of Althaea officinalis, Ziziphus spinachirsti and Myrtus communis as a detergent, seeds of Citrullus colocyanthis, Citrus media, Capparis spinosa for endoparasite. During the last two 
decades, there has been remarkable scientific research on the workability of traditional medicinal herbs which use by pastoralists. For instance, P.harmala has been used as a traditional medicine for the treatment of various disease, such as lumbago, asthma, colic, jaundice and as a stimulant emmenagogue (Bukhari et al. 2008). From current pharmaceutical studies, additional pharmaceutical applications of $P$. harmala have revealed anti-tumour effect, insecticidal effect, curing malaria, Anti leishmania, anti-spasmodic, anti-histaminic, vasorelaxant effects, wound healing, anti-oxidant activity, immunomodulatory properties, leukemia healing, hypoglycemic effects, analgesic and anti-inflammatory (Asgarpanah and Ramezanloo 2012). Some of these traditional herbs which grow in the Pasargadae region are mentioned in Table 1 (see Table 1).

Table 1. Selected Medicinal Plants Mentioned in the Avesta

\begin{tabular}{|c|c|c|c|c|}
\hline $\begin{array}{l}\text { Scientific } \\
\text { Name }\end{array}$ & $\begin{array}{l}\text { Old Name } \\
\text { in Avesta }\end{array}$ & Ancient Indication & New Study & Indication \\
\hline $\begin{array}{l}\text { Althaea } \\
\text { officinalis }\end{array}$ & Holyoum & $\begin{array}{c}\text { Constipation } \\
\text { treatment, Sciatica } \\
\text { remedy, Disinfectant }\end{array}$ & $\begin{array}{l}\text { (Watt et al. } \\
\text { 2007) }\end{array}$ & $\begin{array}{l}\text { Antibacterial activity } \\
\text { against E.coli }\end{array}$ \\
\hline $\begin{array}{l}\text { Boswellia } \\
\text { carterii }\end{array}$ & Hugun & $\begin{array}{c}\text { Disinfectant, } \\
\text { Aromatic, Increasing } \\
\text { the intelligence of } \\
\text { children }\end{array}$ & $\begin{array}{c}\text { (Chevrier et al. } \\
\text { 2005) }\end{array}$ & $\begin{array}{c}\text { Disinfectant, } \\
\text { Amnesia, Asthma, } \\
\text { Cough, Peptic ulcer }\end{array}$ \\
\hline $\begin{array}{l}\text { Bunium } \\
\text { persicum }\end{array}$ & - & $\begin{array}{l}\text { Anticonvulsants, } \\
\text { digestible, anti- } \\
\text { parasite }\end{array}$ & $\begin{array}{l}\text { (Moghtader et } \\
\text { al. 2009) }\end{array}$ & $\begin{array}{c}\text { Strong anti-bacterial } \\
\text { effects, antioxidant } \\
\text { properties }\end{array}$ \\
\hline $\begin{array}{l}\text { Foeniculum } \\
\text { vulgare }\end{array}$ & Kakole & $\begin{array}{l}\text { Expulsion of kidney } \\
\text { stone, Antispasmodic } \\
\text { and anti-bloating, } \\
\text { eroticism enhancer }\end{array}$ & $\begin{array}{c}\text { (Kaur and } \\
\text { Arora 2009) }\end{array}$ & Antibacterial activity \\
\hline $\begin{array}{l}\text { Plantago } \\
\text { ovata }\end{array}$ & - & $\begin{array}{l}\text { Hot fever, Intestinal } \\
\text { ulcer, Constipation } \\
\text { treatment }\end{array}$ & $\begin{array}{l}\text { (Westerhof et } \\
\text { al. 2001) }\end{array}$ & $\begin{array}{l}\text { Wound cleansing and } \\
\text { healing properties }\end{array}$ \\
\hline $\begin{array}{l}\text { Cannabis } \\
\text { satvia }\end{array}$ & - & $\begin{array}{l}\text { Anesthetic, } \\
\text { Abortifacient }\end{array}$ & $\begin{array}{c}\text { (Zuardi et al. } \\
\text { 2006) }\end{array}$ & Antipsychotic drug \\
\hline $\begin{array}{c}\text { Melissa } \\
\text { afficianalis }\end{array}$ & Vatrang & Sedative & $\begin{array}{c}\text { (Akhondzadeh } \\
\text { et al. 2003) }\end{array}$ & Alzheimer's disease \\
\hline $\begin{array}{l}\text { Thymus } \\
\text { vulgaris }\end{array}$ & Avisan & Stomachic & $\begin{array}{c}\text { (Sokovic et al. } \\
2010)\end{array}$ & Antibacterial effect \\
\hline $\begin{array}{l}\text { Mandragora } \\
\text { afficinalis }\end{array}$ & Mirogya & Sedative & $\begin{array}{c}\text { (Perry et al. } \\
1998)\end{array}$ & Alzheimer's disease \\
\hline $\begin{array}{l}\text { Ephedra } \\
\text { vulgaris }\end{array}$ & $\begin{array}{l}\text { Haoma, } \\
\text { Hom }\end{array}$ & $\begin{array}{l}\text { Religious mythical } \\
\text { plant, Stimulant }\end{array}$ & $\begin{array}{c}\text { (Baily and Day } \\
1989)\end{array}$ & Diabetes treatment \\
\hline $\begin{array}{l}\text { Peganum } \\
\text { harmala }\end{array}$ & Spand & $\begin{array}{c}\text { Antiseptic, Protection } \\
\text { of devil eye as } \\
\text { fumigation }\end{array}$ & (Nenaah 2010) & $\begin{array}{l}\text { Antibacterial and } \\
\text { antifungal activity }\end{array}$ \\
\hline $\begin{array}{c}\text { Myrtus } \\
\text { communis }\end{array}$ & Murta & Antiseptic & $\begin{array}{c}\text { (Elfellah et al. } \\
1984)\end{array}$ & Diabetes treatment \\
\hline $\begin{array}{l}\text { Calendula } \\
\text { officinalis }\end{array}$ & Aerakeona & Dramatic & $\begin{array}{l}\text { (Roopashree et } \\
\text { al. 2008) }\end{array}$ & Antibacterial activity \\
\hline $\begin{array}{l}\text { Lavandula } \\
\text { Officinalis }\end{array}$ & - & $\begin{array}{c}\text { Epilepsy, } \\
\text { sleeplessness, } \\
\text { obsession and } \\
\text { infective disease }\end{array}$ & $\begin{array}{c}\text { (Rabiei et al. } \\
\text { 2014) }\end{array}$ & $\begin{array}{l}\text { Effect on memory } \\
\text { and learning }\end{array}$ \\
\hline
\end{tabular}




\section{The Main Challenges of Health Tourism in Pasargadae}

Although tourism development due to its several advantages seems inevitable, still the problems and obstacles such as the poor transportation system or the lack of standard hotels or recreational facilities as serious infrastructural problems delay the development of health tourism in the Pasargadae region. In addition, the lack of a treatment visa and, consequently, the inability to use medical insurance, social challenges such as lack of public knowledge as tourist attractions as for tourism and national tourism attractions, enough comfort, health, and medical facilities, effective sanitary systems, political problems (US sanctions on Iran, Iran's policy in the region and with Western countries) are ahead of the tourism industry in this region. Therefore, it can be said that Lack of infrastructural institutes for provision and improvement of quality and standard of the services, creation a dual market structure in health services, non-portability of health insurances and lack of private sector by the government are highlighted as the most important challenges which Iran health tourism faced by (Heng Leng 2007) and (Tourani et al. 2010). A SWOT analysis can make clear the potential and challenges of health tourism in the Pasargadae region (see Table 2). To achieve the main goals and informing the later steps, identification of SWOT is necessary. In the process of analysis, the priorities in the field of tourism are:

- Constructing of application infrastructure and improving the quality of services.

- Developing human resources and institutional investments.

- Advertising in order to attract tourists and introduce the attractions of this region.

- Identification, promotion, and presentation of native and tourism products for local motivation and economic development (Goodarzi, Haghtalab, \& Shamshiry, 2015).

Table 2. SWOT Table of Health Tourism in Pasargadae Region

\begin{tabular}{|c|c|}
\hline Strength & Weakness \\
\hline $\begin{array}{l}\text { - One of the popular and well-known tourist } \\
\text { place in Iran because of Pasargadae world } \\
\text { heritage site. } \\
\text { - Rich and diverse historical and natural } \\
\text { resources. } \\
\text { - Noticeable clean and quiet Environment. } \\
\text { - One of the origins of using traditional } \\
\text { medicines and medical herb with an honorable } \\
\text { past. } \\
\text { - Specific geographical position (High Zagros } \\
\text { mountain and Morghab plain) which has led to } \\
\text { affluence and diversity of native herbs with } \\
\text { unique remedial effect. } \\
\text { - The plurality of ancient, historical, cultural } \\
\text { and religious monuments and site. } \\
\text { - Preserved vibrant rural areas with rich } \\
\text { culture and traditional lifestyle. }\end{array}$ & $\begin{array}{l}\text { - Lack of a clear description of the capacity } \\
\text { of tourists attraction, the quality of services } \\
\text { and essential facilities. } \\
\text { - Lack of developed tourism infrastructure } \\
\text { in most part of the municipality. } \\
\text { - Unorganized marketing in the field of } \\
\text { tourism especially health tourism. } \\
\text { - Restlessness, tensions, and insecurity } \\
\text { neighboring countries, which has led to the } \\
\text { wrong perception of international tourists } \\
\text { regarding Iran and decreasing the number of } \\
\text { international tourists. } \\
\text { - The difficulties of international tourism } \\
\text { development despite united state political } \\
\text { sanction against Iran. } \\
\text { - Lack of sufficient planning to protect the } \\
\text { environment by expanding tourism absorption. }\end{array}$ \\
\hline
\end{tabular}


- Remaining ceremonies and cultural, social and traditional events such as the celebration of harvesting agricultural products, traditional sports competition, dancing, marriage, and birth of a child ceremony.

- The hospitable and friendly behavior of the residents.

- Native and various handicrafts and food products.

- Varied traditional and healthy dishes and drinks.

- Is adjacent to international borders. (ShirazIsfahan-Yazd road)

- Demand in neighboring countries and the middle east which have a weak medical system in comparison to Iran, such as Pakistan, Afghanistan, Iraq, and Syria.
- Lack of adequate public transportation.

- The inability of people to speak in an international language such as English or French.

- Lack of comprehensive strategies and scheme to develop health tourism, legal and public restriction in the field of health tourism.

- Lack of recreational and tourism services centres.

- Lack of training systems for catering and tourism that led to the work of nonspecialized human resources in this field.

- Limited advertising and activity of travel agencies which led to a lack of personal investment in health tourism development.

- Problems in providing social and public security especially in remote areas.

- The weakness of the national economy and the high rate of inflation.

- Low cost and affordable services and
facilities.

- Widespread public acceptance of economic development using tourism.

- The high rate of potential and capacity of health village construction.

- Developing demands for health tourism across the world.

- Expensive health services in some countries, especially wealth and western countries.

- The high level of potential tourist in the neighbor and Islamic countries which have a cultural or religious relation.

- The positive impact of tourism development on the local's quality of life.

Treats

- The probability of environmental pollution in pristine areas.

- The possibility of changing the local's culture and lifestyle through familiarity with other culture.

- The possibility of changing the local's lifestyle by increasing the level of income.

- Failure in the development of health tourism and the wasting of the bulk of infrastructure investment.

- Uncontrolled use of traditional medical experiences and it's a negative impact on tourism development.

- Extinction or significant decline of native plants due to increased demand.

\section{Applicable Solution}

This section based on the suggestions by the interpretation of the main objective of this study for Pasargadae region. Some suggestions are expressed as follows:

a. Health village includes a different department:

- Beauty treatment by Using herbal oil, plant extract or traditional bath for beautifying skin and hair with organic material and traditional methods.

- Yoga therapy which leads to stress reduction, breathing improvement and general health of the body (Letho et al. 2015).

- Meditation which causes physiological changes and mental relaxation (Dehghani et al. 2014).

- Mud therapy can prevent many diseases by absorbing toxins in the body. 
- Energy therapy which leads to promoting balance, relaxation, and health by clearing cellular memory through human energy.

- Silence and reflection which can facilitate the expression of feelings and reflection, encourage responsibility and convey empathy.

- Animal therapy that improves social health by decreasing depression, loneliness, sense of isolation, and anxiety.

- Aromatherapy that can cure imbalance and heterogeneity in patients by mixing and implying herbal oil and medical plant's extracts (Letho et al. 2015).

- Breath therapy can decrease stress, pain, anxiety, panic and negative feelings, improving the quality of sleep, and recovering from trauma by getting more oxygen to the body and brain.

- Laugh therapy that can improve quality of life by increasing the level of satisfaction, reducing stress and pain, and regulating blood pressure (Erdman 1994).

- Hot sand therapy that is possible in this region due to Pasargadae's warm weather and is effective in the treatment process of some disease such as muscular system-skeletal, scoliosis, arthritis, and osteoarthritis and rheumatoid (McSymytz 1993).

- Leech therapy that can use for some disease such as skin diseases, pain management, infection, wound management, not healing wounds, erysipelas, herpes, abscesses, and tumors by a systematic process of passing blood from vessels (Singh 2010).

- Massage therapy that can be effective for the relief of pain, swelling, muscle spasm and restricted movement.

b. Sleep camp: Nowadays many of people suffer from insomnia, sleeplessness and sleep disorder because of Spending less time in natural light and more time, at night, in computer light, however, has messed with our circadian rhythm. Insomnia and sleep disorder have a direct effect on consciousness, mood, Memory, and daily performance, also various side effect such as Fatigue, daily sleepiness, decreased memory and concentration, depression, anxiety, high sensitivity, impaired quality of work and life (Mai and Buysse 2008). Sleep camp can improve the quality of sleeping by learning some methods to meditate and prepare physically and mentally for restful sleep and using time in natural light to restore the natural circadian rhythm of the body.

c. Psychiatric rehabilitation institute: Rehabilitation is one of the most important factors in improving patients who suffer from severe and persistent mental illness. The important goal of psychiatric and spiritual rehabilitation is helping the disabled individuals to develop the social, emotional, and intellectual skills needed to live, learn and work in a society with the least amount of professional support. This institution provides a comprehensive program to assist persons to meet their individual needs and recover from their illness (Roessler 2006). 
d. Recovery homes for critical illness: More than one out of three survivors of critical illness experience depression long after recovering from the initial illness. In addition, life-threatening illness can significantly affect emotional and psychological well-being. Constructing these houses in nature can be effective in decreasing the recovery period due to the healing energy of nature (Elliott et al. 2011).

e. Launching clinic of traditional medicine with herbal therapy: The diversity of medical herb in this region and the deep knowledge in traditional medicine are made the potential of constructing clinic for curing patient whom suffering from the mental and physical disease.

f. Diversifying health tourism products: providing varied health tourism products in a package to health tourists such as medical juice or tea, herbal cream or soap, food spices for controlling body nature related to Iranian traditional medicine, production of herbal medicines in tablet, capsule or syrup form and so forth.

\section{Conclusion}

Pasargadae region is one of the best areas for appealing tourists due to historical and natural resources that are strong features to construct an ideal health village. Hence, this paper has tried to reveal the high potential of health tourism in this unique region with a focus on four capacities (pure nature, a particular lifestyle, traditional medicine, and medical herbs). Pasargadae health tourist attraction could be strengthened and changed into the first destination of this type of tourism among the Asian countries, due to the rich culture, human capital, and natural resources. Mentioned study results identified significant implications for the development of health tourism in this region. SWOT Analysis has attempted to promote tourism capacity in the region by developing strengths and altering weaknesses into strengths and opportunities by offering some strategies. However, the attraction of investors to create hotels and other tourism infrastructure in the region as well as the cooperation of the organizations of Pasargadae region in this regard could be a way to turn the main weak points into the strengths. Undoubtedly, developing health tourism have numerous advantages such as increasing individual investment, improving the rate of employment, enhance the feeling of dependency for the local residents. Nevertheless, enlarging this industry dependence on some of the basic infrastructure. Among the above-mentioned infrastructures, can mention the use of human resources with training in various aspects, the standardization, and classification of tourist facilities and the preservation of the unique natural geographical situation of the area. According to these arguments, if existing opportunities for the valorization of resources considered properly and managed successfully, sustainable tourism development with a focus on health tourism in the Pasargadae region will not unexpected. Further, it is vitally important to emphasize the principle weaknesses and take advantages of opportunities to address the weaknesses of the issue of health tourism in the region. 


\section{References}

Adhami H, Mesgarpour B, Farsam H (2007) Herbal medicine in Iran. Herbal Gram 74: 34-43.

Akhondzadeh S, Noroozian M, Mohammadi S, Ohadinia A, Jamshidi H, Khani M (2003) Melissa officinalis extract in the treatment of patients with mild to moderate Alzheimer's disease: a double-blind, randomized, placebo-controlled trial. Journal of Neurology, Neurosurgery \& Psychiatry 74(7): 863-866.

Asgarpanah J, Ramezanloo F (2012) Chemistry, pharmacology and medicinal properties of Peganum harmala L. African Journal of Pharmacy and Pharmacology 6(22): 1573-1580.

Avicenna (1991) The Canon of Medicine. Tehran: Soroosh publisher.

Bahrami B, Aminzadeh B, Samani F (2007) The effect of hydrologic systems on formation of the archaeological site of Pasargadae. Journal of Environmental Studies 43: 131142.

Baily C, Day C (1989) Traditional plant medicines as treatments for diabetes. Diabetes Care 12(8): 553-564.

Bakhtiari M (2005) Strategic Model for Khatam Al Anbia Hospital. Master thesis, University of Tehran.

Beck L (1998) Use of Land by Nomadic Pastoralists in Iran. Middle Eastern Natural Environments 103: 72-93.

Bukhari N, Choi J, Jeon C, Park H, Kim W, Khan M, et al. (2008) Phytochemical studies of the alkaloids from Peganum Harmala. Applied Chemical 12(1), 101-104.

Chevrier M, Ryan A, Lee D, Zhongze M, Wu-Yan Z, Via C (2005) Boswellia carterii Extract Inhibits TH1 Cytokines and Promotes TH2 Cytokines In Vitro. Clin diagn Lab Immunol 12(5): 257-280.

Dehghani S, Amini K, Shakibazade E, Faghihzade S, Hashemzade M (2014) Meditation impact of 2 heart on nervous amount of hemodializ sicks. Journal of Preventive Care in Nursery and Midwifery 2: 56-65.

Elfellah M, Akhtar H, Khan T (1984) Anti-hyperglycaemic effect of an extract of Myrtus communis in streptozotocin-induced diabetes in mice. Journal of Ethnopharmacology 11(3): 275-281.

Elliott D, McKinley S, Alison J, Atiken L, King M, Leslie G, Kenny P, Taylor P, Foley R, Burmeister E (2011) Health-related quality of life and physical recovery after a critical illness: a multi-centre randomized controlled trial of a home-based physical rehabilitation program. Critical Care 15(3): 142-148.

Erdman L (1994) Laughter therapy for patients with cancer. Journal of Psychosocial Oncology 11(4): 55-67.

Gabor M, Oltean F (2019) Babymoon tourism between emotional well-being service for medicaltourism and niche tourism. Development and awareness on Romanian educated women. Tourism Management 70: 170-175.

Gershevich I (2006) Cambridge history of Iran (Achaemenid Empire). (M. Saghebfar, Trans.) Tehran: Amirkabir publisher.

Ghafari S, Ahmadi F, Nabavi S (2008) Survey about impact of water therapy on M.S. sick tiredness. Mazandaran University of Medical Science Journal 66: 71-81.

Gholipour H (2005) Green Ruby: History, Geography, and Culture of Pasargadae City Sa'adat Shahr. Shiraz: Navid Publication.

Goodarzi M, Haghtalab N, Shamshiry E (2015) Wellness tourism in Sareyn, Iran: resources, planning and development. Current Issues in Tourism 19(11): 1071-1076. 
Hamedi A, Zarshenas M, Sohrabpour M, Zargaran A (2013) Herbal medicinal oils in traditional Persian medicine. Pharmaceutical Biology 51(9): 1208-1218.

Hashemian K (2004) The influence of Psychoanalytic thought in music therapy. $4^{\text {th }}$ Congress on Music Application in Mental and Physical Health VI(1): 96-112.

Heng Leng C (2007) Medical tourism in Malaysia: international movement of health care consumers and the commoditization of health care. Singapour: Asia Research Institute of National University of Singapore.

Hosseini M, Atashpour H, Aghai A (2008) Psychology on Education Spaces Architecture of Healthy City. First Congress of Healthy City, Tehran.

Irani Behbahani H, Bahrami B, Aqa Ebrahimi F (2010) Multidisciplinary analysis of nature, culture, and history in archaeological landscape of Iran. Environmental Science 7(3): 103-116.

Izadi M, Saadat S, Ayoubian A, Hashemi Dehaghi Z, Karbasi M, Jalali A (2013) Health Tourism in Iran; Identifying Obstacles for Development of This Industry. International Journal of Travel Medicine \& Global Health 1(2): 89-94.

Jabbari A (2009) Designing a model for Iran medical Tourism. Iran: University of medical sciences, thesis.

Kaur G, Arora D (2009) Antibacterial and phytochemical screening of Anethum graveolens, Foeniculum vulgare and Trachyspermum ammi. BMC Complement Alternative Medicine 30-35.

Kazemi Z (2007) Study of the effective factors for attracting medical tourism in Iran. Master thesis, Lulea University of Technology.

Letho X, Brown S, Chen Y, Morrison A (2015) Yoga Tourism as a Niche Within the Wellness Tourism Market. Tourism Recreation Research 31: 25-35.

Mai E, Buysse D (2008) Insomnia: Prevalence Impact, Pathogenesis, Differential Diagnosis, and Evaluation. Sleep Med Clin 3(2): 167-174.

McSymytz L (1993) Hot/dry, hot/moist or cold therapy pad. U.S. Patent 5,179,944.

Moghadamzadeh A, Zargaran A, Daneshamuz S (2011) Cosmetic sciences from ancient Persia. Pharmaceutical Historian 41(2): 18-23.

Moghtader M, Mansouri I, Salari H, Farahmand A (2009) Chemical composition and antimicrobial activity of the essential oil of Bunium persicum Boiss. Iranian Journal of Medical Aromatic Plants 25: 20-28.

Nadim Z, Gandomkar A (2016) Planning for wellness tourism center in Isfahan province, Iran. Open Journal of Ecology 6(10): 645-657.

Naghibi F, Mosaddegh M, Mohammadi Motamed S, Ghorbani A (2005) Labiatae family in folk medicine in Iran: From ethnobotany to pharmacology. Iranian Journal of Pharmaceutical Research 2: 63-79.

Nenaah G (2010) Antibacterial and antifungal activities of (beta)-carboline alkaloids of Peganum harmala (L) seeds and their combination effects. Fitoterapia 81(7): 779782.

Perry E, Picker A, Wang W, Houghton P, Perry N (1998) Medicinal plants and Alzheimer's disease: Integrating ethnobotanical and contemporary scientific evidence. The Journal of Alternative and Complementary Medicine 4(4): 419-428.

Rabiei Z, Rafieian-Kopaei M, Mokhtari S, Alibabaei Z, Shahrani M (2014) The effect of pretreatment with different doses of Lavandula officinalis ethanolic extract on memory, learning, and nociception. Biomedicine \& Aging Pathology 4(1): 71-76.

Roessler W (2006) Psychiatric rehabilitation today: an overview. World Psychiatry 5(3): 151-157.

Rokni L, Pourahmad A, Moteiey M, Rezaeiy Mahmoudi M, Heidarzadeh N (2013) Appraisal the Potential of Central Iran, in the Context of Health Tourism. Iranian Journal Publication Health 42(3): 272-279. 
Roopashree T, Raman Dang R, Shobha R, Narendra C (2008) Antibacterial activity of antipsoriatic herbs: Cassia tora, Momordica charantia, and Calendula officinalis. International Journal of Applied Research in Natural Products 1(3): 20-28.

Sabzalian F (2004) Healing with Extrasensory. Faragoft publication.

Saeedi S (2005) Anthropological study of Pasargadae Region. Pasargadae: Pasargadae World Heritage Site.

Samani B (2002) Geomorphology and Tectono Eustatic Evolution of Zagros Folded Belt. Tehran: Nazli Exploration and Geology Company, report, in Farsi.

Sedaghat Kish J (2000) The Tomb of Cyrus and the Beliefs of the People of Fars. Tehran: Khojaste.

Shalbafian A (2006) The Ways of Health Tourism Development. Master thesis, University of Alameh Tabatabaee.

Singh A (2010) Medicinal leech therapy (hirudotherapy): a brief overview. Complementary Therapies in Clinical Practice 16(4): 213-215.

Smith M (2010) Key concepts in tourist studies. Los Angles: SAGE publication.

Sokovic M, Glamocliina J, Marin P, Brkic D, Van Griensven L (2010) Antibacterial effects of the essential oils of commonly consumed medicinal herbs using an in vitro model. Molecules 15(11): 7532-7546.

Tourani S, Tabibi J, Shaarbafchi Zadeh N (2010) Medical Tourism in Iran: Analysis of Opportunities and Challenges with MADM Approach. Research Journal of Biological Sciences 5(3): 251-257.

Vajirakachorn T (2004) Implementation of an Effective Health Tourism Development Plan for Thailand. University of Wisconsin-Sout.

Watt K, Christo N, Young R (2007) The detection of antibacterial actions of whole herb tinctures using luminescent Escherichia coli. Phytother Res 21(12): 1193-1199.

Westerhof W, Das P, Middelkoop E, Verschoor J, Storey L, Regnier C (2001) Mucopolysaccharides from psyllium involved in wound healing. Drugs and Experimental Clinic Research 27(5-6): 165-175.

Zuardi A, Crippa J, Hallak C, Moreira A, Guimaraes F (2006) Cannabidiol, a Cannabis sativa constituent, as an antipsychotic drug. Brazillian journal of Medical and Biological Research 39(4): 421-429. 